\title{
Article \\ The Impact of Forest Fungi on Promoting Growth and Development of Brassica napus L.
}

\author{
Grażyna B. Dąbrowska ${ }^{1}{ }^{\mathbb{D}}$, Zuzanna Garstecka ${ }^{1}$, Alina Trejgell ${ }^{2}$, Henryk P. Dąbrowski ${ }^{3}$, Wiktoria Konieczna ${ }^{1} \mathbb{D}$ \\ and Iwona Szyp-Borowska ${ }^{4, *}$
}

1 Department of Genetics, Faculty of Biological and Veterinary Sciences, Nicolaus Copernicus University in Toruń, 87-100 Toruń, Poland; browsk@umk.pl (G.B.D.); znajewsk@doktorant.umk.pl (Z.G.); wpyrkosz@doktorant.umk.pl (W.K.)

2 Department of Plant Physiology and Biotechnology, Faculty of Biological and Veterinary Sciences, Nicolaus Copernicus University in Torun, 87-100 Torun, Poland; trejgell@umk.pl

3 Dendroarchaeological Laboratory, Biskupin Archaeological Museum, Biskupin, 88-410 Gąsawa, Poland; hpdabrowski@biskupin.pl

4 Department of Silviculture and Genetics of Forest Tree, Forest Research Institute, Braci Lesnej Street, No 3, Sekocin Stary, 05-090 Raszyn, Poland

* Correspondence: I.Szyp@ibles.waw.pl

Citation: Dąbrowska, G.B.;

Garstecka, Z.; Trejgell, A.; Dąbrowski, H.P.; Konieczna, W.; Szyp-Borowska, I. The Impact of Forest Fungi on Promoting Growth and Development of Brassica napus L. Agronomy 2021, 11, 2475. https://doi.org/10.3390/ agronomy11122475

Academic Editor: Federico Vita

Received: 27 October 2021

Accepted: 2 December 2021

Published: 6 December 2021

Publisher's Note: MDPI stays neutral with regard to jurisdictional claims in published maps and institutional affiliations.

Copyright: (c) 2021 by the authors. Licensee MDPI, Basel, Switzerland. This article is an open access article distributed under the terms and conditions of the Creative Commons Attribution (CC BY) license (https:/ / creativecommons.org/licenses/by/ $4.0 /)$.

\begin{abstract}
Inoculation of plants with fungi has been shown to increase yields by improving germination, seedling vigor, plant growth, root morphogenesis, photosynthesis, and flowering through direct or indirect mechanisms. These mechanisms include solubilization and mineralization of nutrients, facilitating their uptake by plants, regulation of hormone balance, production of volatile organic compounds and microbial enzymes, suppression of plant pathogens, and mitigation of abiotic stresses. In the presented experiments, the effect of selected forest soil fungi on the growth and development of Brassica napus L. seedlings was investigated. Inoculation was carried out in vivo and in pot experiments with ectomycorrhizal and fungi typical for forest soils: Collybia tuberosa, Clitocybe sp., Laccaria laccata, Hebeloma mesophaeum, and Cyathus olla. It was shown that all analyzed fungi produced IAA. In the in vitro experiment, B. napus inoculated with L. laccata showed stimulated root growth and greater number of leaves compared to control plants. A similar stimulatory effect on lateral root formation was observed in cuttings grown in pots in the presence of the C. olla fungus. In the pot experiment, the seedlings inoculated with the L. laccata fungus also showed increased growth of shoots and biomass. The effect of inoculation with the tested fungal strains, especially $C$. olla, on the growth and development of oilseed rape was probably indirect, as it also contributed to an increase in the number of microorganisms, especially soil bacteria. The expression of the metallothioneins in B. napus (BnMT1-BnMT3) varied depending on the fungal species. The presence of $C$. olla significantly increased BnMT2 expression in oilseed rape. It was found that BnMT1 expression increased and BnMT3 transcripts decreased in plants growing in the presence of L. laccata. This indicates the involvement of BnMT in the adaptation of oilseed rape to growth in fungi presence.
\end{abstract}

Keywords: agroforestry; Cyathus olla; Laccaria laccata; metallothioneins; rapeseed

\section{Introduction}

The close proximity of two areas of completely different land use, and hence soil quality and species richness (in both plants and microorganisms), means that the proximity of forest and cropland creates an area of mutual influence. These relationships can be both harmful and beneficial to both parties. The positive effect of agroforestry can be seen in the production of plant biomass, especially in light soils (and sand in particular) with low water capacity, high permeability, and considerable susceptibility to wind erosion, especially in years when extreme weather situations prevail, e.g., severe drought [1]. It has been shown that habitat improvement through contact with tree stands can increase 
yields of spring cereals by $12 \%$, winter cereals by $18 \%$, and root crops and legumes by $5 \%$, especially in dry years [1]. Soil microorganisms interact with each other and with plants, ensuring the maintenance of the ecological balance in the soil. The interactions between plants and microorganisms are very important as they affect the bioavailability of nutrients and thus the yield of plants. As a result, these interactions affect soil welfare and plant survival, especially under unfavorable conditions [2]. Microorganisms, including fungi, have a positive effect on plant vegetation by supporting their growth both directly and indirectly $[3,4]$. The presence of fungi has a positive effect on soil parameters and plant microbiome, and indirectly on plant growth and resistance [5-7]. Fungi are involved in all major ecological processes, either directly or indirectly. As saprophytes, they control the carbon cycle by preventing excessive accumulation of organic matter through decomposition into compounds that can be used by other organisms [2]. They increase water uptake and mineral supply to plant, and protect them from pathogens and environmental stress. The commonly reported effects are increases in biomass production, flowering, root hair development, and yield [8,9]. In arable soils, symbiotic endomycorrhizal fungi dominate, colonizing the roots of nearly $90 \%$ of herbaceous plants, but we find virtually no trace of the presence or activity of ectomycorrhizal fungi and saprotrophic fungi [10], which mostly form symbiotic relationships with forest trees. Saprotrophic fungi have a positive effect on plants, for example, by producing enzymes that facilitate the transformation of humic substances and the formation and mineralization of humus [10]. The production of enzymes enables plants to utilize organic $\mathrm{N}$ and $\mathrm{P}$ forms that would otherwise be largely unavailable to roots [11]. The production of organic acids leads to chemical leaching of mineral surfaces and mobilizes nutrients such as $\mathrm{P}, \mathrm{K}, \mathrm{Ca}$, and $\mathrm{Mg}$ that can be transferred to host plants [12-15]. However, the role of fungi is not limited to stimulating plant nutrition, but can also be associated with increasing root absorptive surface area and increasing plant stress tolerance, among other effects [16].

Basidiomycete fungi are dominant decomposers and mycorrhizal mutualists in soils [17]. They produce a variety of enzymes that can degrade major components of plant cell walls [18]. In soil they form an extensive network of hyphae, and they secrete metabolites composed of glucolipids, polysaccharides, and glycoproteins. It is known that these products have antimicrobial activities, and play a role in soil aggregation and stabilization $[19,20]$. Under the influence of fungal inoculation, the gene expression profile changes. Studies have confirmed that among genes overexpressed during fungal-plant interaction are those encoding for metallothioneins (MTs).

Metallothioneins have been identified in angiosperm species, both monocotyledonous and dicotyledonous, and in some gymnosperms, ferns, and bryophytes [21-23]. MTs are low molecular weight proteins (from 5 to $10 \mathrm{kDa}$ ). Cysteine residues account for between $15 \%$ and $30 \%$ of the total amino acid pool, giving MTs the ability to coordinate the binding of various metals from groups 11 and 12 of the periodic table. MTs are involved in the maintenance of micronutrient homeostasis, especially of $\mathrm{Zn}$ and $\mathrm{Cu}$, and furthermore in the detoxification of toxic metals $(\mathrm{Cd}, \mathrm{Pb})$ [24-26]. The induction of MTs expression depends on many biotic and abiotic factors. Cis-elements responsible for the response to the presence of fungal elicitors are present in the MT genes promoters [27]. In higher plants, individual types of metallothioneins show organ- and tissue-specific expression, but expression can differ greatly between species [28-30]. In Brassica napus, there are four types of MT (BnMT1-BnMT4), of which type 4 (BnMT4) is expressed only in seeds and early stages of seedling growth [30,31].

Plants in the Brassicaceae family are non-mycorrhizal organisms. Glenn et al. [32] showed that the arbuscular mycorrhizal fungus Glomus mosseae penetrate Brassica roots, but mycelial hyphae, which only penetrate the dead cells of the root cortex, were unable to establish functional cooperation with the plant. However, Tommerup [33] demonstrated the presence of reduced arbuscules in B. napus, so that a positive effect of mycorrhizal fungi and other soil fungi on the growth of oilseed rape cannot be excluded. Also of interest are reports of some soil fungi that have the ability to function near plants containing 
isothiocyanates, including plants of the Brassicaceae family [34]. Studies have shown that basiciomycete fungi, Piriformospora indica, promoted the growth and development of sweet potato. Moreover $P$. indica also increased the resistance of potato to biotic and abiotic stresses [35].

The effects of fungi on non-mycorrhizal plants and on stress-tolerance mechanisms are still poorly understood. An example is a study of Zhang et al. [36], in which 97 endophytic fungi were isolated from the roots, stems, and leaves of $B$. napus. The authors identified 40 fungal species, $80 \%$ of which belong to the Ascomycota. Some of the fungi, i.e., Aspergillus flavipes, Chaetomium globosum, Clonostachys rosea, and Leptosphaeria biglobosa, showed antagonism to the oilseed rape pathogen Sclerotinia sclerotiorum. Furthermore, Alternatia alternata CanL-18, Fusarium tricinctum CanR-70 and CanR-71r, and Leptosphaeria biglobosa CanS-51 showed a growth-promoting effect on B. napus. Studies by Znajewska et al. [7] showed the stimulatory effect of Trichoderma sp. fungi on germination and early growth stages of oilseed rape. A similar positive effect on the growth of this crop was found for the presence of Acaulospora longula, Glomus geosporum, Glomus mossae, and Scutellospora calospora [37].

The aim of the study was to assess the impact of inoculation with fungi typical of forest soils (Clitocybe sp., Collybia tuberosa, Cyathus olla, Hebeloma mesophaeum, and Laccaria laccata) on the growth and development of $B$. napus seedlings in vitro and in pot experiments, and to determine changes in bacteria and fungi populations in soil after pot experiments. MT promoters in Arabidopsis thaliana and Oryza sativa contain regulatory sequences of response to fungal elicitors [38], and we suppose that these genes may be involved in plants' adaptation to changes in environmental conditions. We also studied changes in $M T$ gene expression in rapeseed (Brassica napus L.) in response to inoculation with saprofitic fungi.

\section{Materials and Methods}

The study material comprised seeds and plants of the B. napus variety Clipper (AgroBras, Wagrowiec, Poland). Seeds previously sterilized in $70 \%$ ethyl alcohol for $1 \mathrm{~min}$ were used for the in vitro experiment. Basic sterilization was performed with a $30 \%$ sodium hypochlorite solution (Domestos, Unilever, Warszawa, Poland) for $30 \mathrm{~min}$. Sterile seeds were also used for the pot experiment. The fungi used in the study were: Laccaria laccata (Scop.) Cooke, Clitocybe sp., Collybia tuberosa (Bull.) P. Kumm., Hebeloma mesopheum (Pers.) Quel, and Cyathus olla (Batsch) Pers. which were provided by prof. Katarzyna Hrynkiewicz from the Department of Microbiology, Nicolaus Copernicus University in Torun.

\subsection{Preparation of Inoculum from Fungi}

Fungal strains were propagated on microbiological PDA medium (Potato Dextrose Agar) (Difco Laboratories, Detroit MI, USA) prepared according to the manufacturer's instructions. Fragments of individual mycelium $(5.0 \times 5.0 \mathrm{~mm})$ were excised with a scalpel and transferred to fresh PDA medium. The dishes were incubated at $25^{\circ} \mathrm{C}$. Cultivation continued until the dish was overgrown by the fungal strain under study, which was then used to inoculate $B$. napus seedlings in the in vitro and pot experiments.

\subsection{In Vitro Experiment}

Sterile seeds (20-30 items) were placed in $150 \mathrm{~mm}$ diameter Petri dishes containing MS medium without growth regulators (MS0, Murashige and Skoog [30]) and placed in a culture chamber (continuous light, temperature $25 \pm 1{ }^{\circ} \mathrm{C}$ ). Three to four days after sowing, four rapeseed seedlings with similar root length $(1-2 \mathrm{~cm})$ were transferred into sterile dishes containing MS0 medium. Two fragments of different strains of mycelium $(5.0 \times 5.0 \mathrm{~mm})$ were introduced into the root zone between 2 seedlings at the same distance.

Seedlings that were not inoculated with mycelial fragments served as control material. Plates containing the co-culture were wrapped in parafilm and placed vertically. The coculture was carried out for 10 days under continuous light and at $25 \pm 1{ }^{\circ} \mathrm{C}$. The length of 
roots and shoots and the number of lateral roots and leaves were analyzed. The experiment was carried out in three replicates.

\subsection{Pot Experiment}

Seeds of B. napus were placed in $2200 \mathrm{~mL}$ pots with soil mixed with vermiculite in a ratio of 2:1. The soil had the following parameters: $8.02 \%$ organic matter $(\mathrm{OM}) ; 3.71 \%$ organic carbon (Corg); $0.303 \%$ nitrogen (Nt); $1 / 2$ ratio of carbon to nitrogen $(\mathrm{C} / \mathrm{N}) ; 1.29 \%$ $\mathrm{CaCO}_{3} ; \mathrm{pH}$ 7.27. After germination, four seedlings were left in each pot. On day 28 of the experiment, plants were inoculated with individual fungi so that each plant had a $5.0 \times 5.0 \mathrm{~mm}$ fragment of mycelium placed in its rhizosphere zone at a depth of $2-3 \mathrm{~cm}$. Inoculation was repeated on day 56 of cultivation. Plants that were not inoculated with fungi served as controls. The experiment was conducted in three replicates for 16 weeks in a culture chamber under continuous light and at a temperature of $25 \pm 1{ }^{\circ} \mathrm{C}$. On day 84 of the experiment, chlorophyll content of leaves, shoot length, number of leaves, and fresh and dry biomass were analyzed. Chlorophyll content was determined using a CCM-200 plus Chlorophyll Content Meter (Opti-Sciences, Hudson, NH, USA). Measurements were taken on three leaves of each plant per variant and the values averaged.

\subsection{Analysis of Microorganism Abundance in Soil}

Averaged soil samples (10 g) of each variant were suspended in $90 \mathrm{~mL}$ sterile water and shaken for $10 \mathrm{~min}$. The serial dilution method yielded suspensions at $10^{-5}$ (for bacteria) and $10^{-3}$ (for fungi) dilutions. The soil suspensions were inoculated by pour plating. To analyze the abundance of fungi in the soil, $1 \mathrm{~mL}$ of the soil suspension was mixed with $20 \mathrm{~mL}$ of PDA medium containing tetracycline $(0.0001 \mathrm{M})$. The number of bacteria was determined by pour plating on R2A medium (Reasoner's 2A Agar) with nystatin at a concentration of $0.0001 \mathrm{M}$. The plates were incubated in a thermostat at $25{ }^{\circ} \mathrm{C}$. Bacterial colonies and fungi were counted after seven days of incubation.

\subsection{Analysis of IAA Production by Fungi}

IAA and IAA-related compounds were produced according to Gravel et al. [39] with minor adjustments. Liquid cultures of fungi were prepared in $100 \mathrm{~mL}$ flasks containing $20 \mathrm{~mL}$ TSB medium supplemented with $200 \mu \mathrm{g} / \mathrm{mL}$ L-tryptophan or not (control). The culture medium was inoculated with fungal cultures using two PDA disks. The samples were incubated for two weeks at RT on a rotary shaker. Two $\mathrm{m}$ of the supernatant was collected and mixed with Salkowski reagent (0.5M FeCl $\left.3: \mathrm{H}_{2} \mathrm{O}: 70 \% \mathrm{HClO}_{4}, 2: 49: 49\right)$. After $20 \mathrm{~min}$ incubation at RT, absorbance was measured at $535 \mathrm{~nm}$. The concentration of IAA and IAA-related compounds was determined by comparison with a standard curve prepared using serial dilutions of IAA solution (Sigma-Aldrich, Darmstadt, Germany) in TSB.

\subsection{Isolation of Total RNA and Reverse Transcription Reaction}

Total RNA was isolated from the leaves of the plants after three months of rapeseed cultivation using TRI Reagent (Sigma-Aldrich ${ }^{\circledR}$ ) according to the procedure of Chomczyński and Sacchi [40]. The quantity and quality of nucleic acids were evaluated based on the results of spectrophotometric measurement using a NanoDrop 1000 (Thermo Fisher Scientific, Waltham, MA, USA) and electrophoretic separation in 1\% agarose gels. Highquality RNA preparations were used for further analysis, where the $A_{260} / A_{280}$ ratio was approximately 2.0 and the electropherogram of the tested RNA preparations was normal.

The 1.5 micrograms of RNA were treated with 200 U DNase I (Promega GmbH, Mannheim, Germany) and incubated at $37^{\circ} \mathrm{C}$ for $30 \mathrm{~min}$. The enzyme was inactivated by the addition of $0.025 \mathrm{mM}$ EDTA at $65^{\circ} \mathrm{C}$ for $10 \mathrm{~min}$. The whole extract was used for reverse transcription reactions with MMLV-RT (Novozymes, Bagsværd, Denmark) according to the protocol described by Dabrowska et al. [41]. 


\subsection{Semi-Quantitative RT-PCR (sqRT-PCR)}

Rapeseed metallothionein gene sequences from GenBank NCBI (BnMT1: accession no. JX035784.1, BnMT2: JX103200.1, BnMT3: JX103201.1) were used for expression analysis. Semi-quantitative RT-PCR (sqRT-PCR) was used to evaluate the effects of ectomycoryzal fungi on mRNA levels of MT genes in leaves: BnMT1, BnMT2, BnMT3. PCRs were optimized for analysis of the genes in this work. The level of the gene (Bn5S) was used as an internal standard. The PCR mixture included cDNA as template, $0.4 \mu \mathrm{L}$ of $10 \mu \mathrm{M}$ of each primer (Table 1), $0.4 \mu \mathrm{L}$ of $10 \mathrm{mM}$ dNTPs, $2 \mu \mathrm{L}$ of $10 \times$ buffer, and $1.25 \mathrm{U}$ of OptiTaq DNA polymerase (EURx, Gdańsk, Poland) in a total volume of $20 \mu \mathrm{L}$. The thermal cycling conditions were: $95^{\circ} \mathrm{C}$ for $30 \mathrm{~s} ; 52^{\circ} \mathrm{C}(B n M T 1, B n M T 2)$ or $55^{\circ} \mathrm{C}(B n 5 S)$ or $56^{\circ} \mathrm{C}($ BnMT3) for $45 \mathrm{~s}$; and $72{ }^{\circ} \mathrm{C}$ for $35 \mathrm{~s}$ for 26 cycles (BnMT3); $30 \times(B n M T 1, B n M T 2)$. PCR products were separated in 1.5\% agarose gels stained with EtBr in TAE buffer ( $40 \mathrm{mM}$ Tris, $20 \mathrm{mM}$ Acetic acid, $1 \mathrm{mM}$ EDTA) for $40 \mathrm{~min}$ at $80 \mathrm{~V}$. After electrophoresis, the gels were visualized under $\mathrm{UV}$, and their images were used to quantify the amount of PCR product by densitometric examination. ImageGauge 3.46. software (FujiFilm, Tokyo, Japan) was used for signal quantification. Each reaction was repeated three times, and the error bars represent the standard deviation of the mean. Oligonucleotides (Table 1) were synthesized, and the sqRTPCR products were sequenced in the DNA Synthesis and Sequencing Laboratory of IBB PAN in Warsaw (Poland) to confirm that the amplification had been performed correctly.

Table 1. Oligonucleotides used to determine the expression of BnMT1-BnMT3 in rapeseed leaves.

\begin{tabular}{ccc}
\hline Primer Name & Sequence 5 $^{\prime} \mathbf{3}^{\prime}$ & Application \\
\hline BnMT1_for & TGGCAGGTTCTAACTGTGGA & expression of BnMT1 gene \\
BnMT1_rev & CAAATGAAAACATTATACACCACACA & \\
\hline BnMT2_for & TCAATTTGATTAACATTCTCTGCT & expression of BnMT2 gene \\
BnMT2_rev & AAGCCTGCAGCCATTATTACA & \\
\hline BnMT3_for & GCAAAACAACAAAACACACACA & \multirow{2}{*}{ expression of BnMT3 gene } \\
BnMT3_rev & CCATTACATCACACACCATGC & \\
\hline Bn5S_for & AGTCGCACAAATCGTGTCTG & expression of Bn5S reference gene \\
Bn5S_rev & TCCATGCTCTCAGCATCAAC & \\
\hline
\end{tabular}

\subsection{Bioinformatic Analysis of B. napus Metallothionein Gene Promoters}

Promoter sequence of the 17 analyzed genes (714-1500 bp long) were derived from GenBank NCBI (National Center for Biotechnology Information) database (Table S1).

The promoter sequences were used for searching the databases PlantCARE (http: //bioinformatics.psb.ugent.be/webtools/plantcare/html/, accessed on 26 November 2021) [42] and PlantPAN 2.0 (an2.itps.ncku.edu.tw) to identify cis-elements.

\subsection{Statistical Analysis}

Statistical analysis was performed using the program PAST (Paleontological Statistics) [42]. The statistical significance of the results of the physiological parameters of the in vitro and in vivo experiments was determined by a one-way test ANOVA supported by a Kruskal-Wallis test. The Tukey test was used for the results of the soil microbial cultures from the pot experiments. In both cases, the significance threshold was set at $\leq 0.05$.

\section{Results}

3.1. Analysis of the Effect of Ectomycorrhizal Fungi on the Growth of Rapeseed Seedlings In Vitro

The presence of L. laccata, C. tuberosa, and C. olla fungi stimulated root growth compared to non-inoculated seedlings (the control), although the differences were not statistically significant. Conversely, inoculation with $C$. rivulosa fungi significantly inhibited their growth (Table 2). No statistically significant stimulatory effect on lateral root formation was observed in any of the variants, although intense lateral root development was observed in seedlings growing in the presence of C. olla and C. tuberosa fungi (Figure 1). Shoot growth 
was also stimulated by the fungi C. olla and C. tuberosa, although the differences between the inoculated plants and the control were not statistically significant. No statistically significant differences were found in the number of leaves of rapeseed seedlings inoculated with fungi, although L. laccata and C. olla had a stimulatory effect (Table 2). Formation of four or even five leaves was observed in plants inoculated with these fungi, which was not observed in any of the other variants.

Table 2. Biometric parameters of rapeseed on day 10 of in vitro culture (mean value \pm standard deviation) after inoculation with L. laccata, C. tuberosa, Clitocybe sp., H. mesophaeum, C. olla. Values marked with different letters differ significantly at $p \leq 0.05$.

\begin{tabular}{|c|c|c|c|c|}
\hline Variants of Experience & Length of Roots (mm) & Number of Lateral Roots & Length of Shoots (mm) & Number of Leaves \\
\hline control & $114.6 \pm 16.9^{a}$ & $40.2 \pm 7.3^{a b}$ & $54.0 \pm 10.7^{\mathrm{ab}}$ & $3.0 \pm 1.1^{\mathrm{ab}}$ \\
\hline L. laccata & $131.4 \pm 25.0^{a}$ & $35.0 \pm 19.6^{\mathrm{ab}}$ & $58.6 \pm 18.9^{a b}$ & $3.6 \pm 0.9^{a}$ \\
\hline C. tuberosa & $127.2 \pm 12.6^{a}$ & $47.7 \pm 9.3^{a b}$ & $62.8 \pm 10.7^{a}$ & $3.1 \pm 0.3^{a b}$ \\
\hline Clitocybe sp. & $81.5 \pm 7.4^{b}$ & $43.1 \pm 7.8^{b}$ & $54.3 \pm 13.6^{\mathrm{ab}}$ & $3.0 \pm 0.0^{\mathrm{ab}}$ \\
\hline H. mesophaeum & $112.5 \pm 34.1^{a}$ & $38.7 \pm 7.7^{b}$ & $59.8 \pm 12.2^{a b}$ & $3.0 \pm 0.5^{a b}$ \\
\hline C. olla & $117.0 \pm 32.3^{a}$ & $61.0 \pm 26.6^{a}$ & $63.4 \pm 13.3^{\mathrm{a}}$ & $3.6 \pm 0.8^{a}$ \\
\hline
\end{tabular}

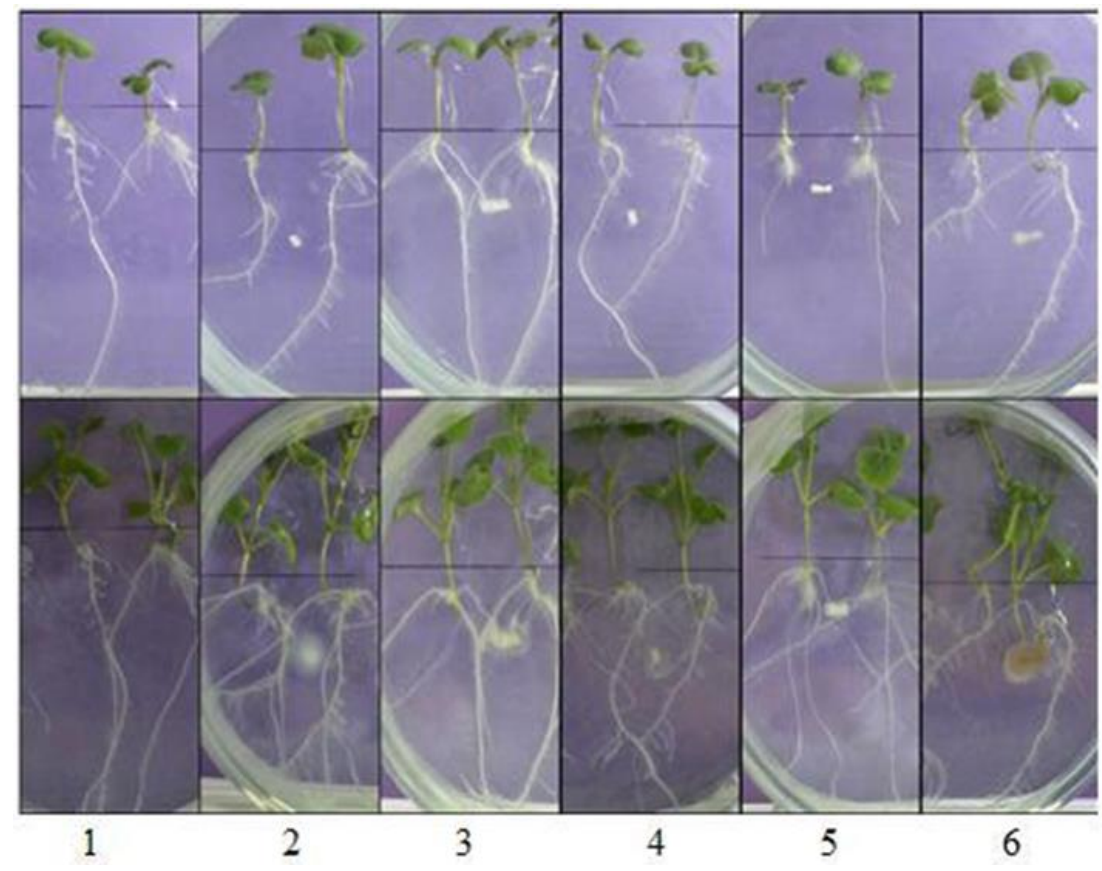

A.

B.

Figure 1. Rapeseed seedlings on day 4 in vitro (A) and day 10 in vitro (B). Order of variants: control (1), L. laccata (2), C. tuberosa (3), Clitocybe sp. (4), H. mesophaeum (5), C. olla (6).

\subsection{Analysis of the Effect of Fungi on the Growth and Development of Rapeseed Shoots in a} Pot Experiment

The highest chlorophyll levels were found in the leaves of non-inoculated plants and of plants inoculated with L. laccata, H. mesophaeum, and C. olla. Conversely, statistically significantly lower chlorophyll content was found in the leaves of plants inoculated with C. tuberosa and Clitocybe sp., which were 2 and 1.4 times lower, respectively, compared to control plants (Table 3). Shoot growth was also inhibited after fungal inoculation-most severely in C. tuberosa, C. olla, and Clitocybe sp.-and the differences were statistically significant. However, this was due to the shortening of internodes rather than their number, as indicated by the higher number of leaves in plants inoculated with the fungus C. olla. Only in plants inoculated with the H. mesophaeum was a lower number observed. The analysis of fresh and dry biomass of the above ground part of the plants showed that the plants inoculated with L. laccata fungus had the highest biomass, whereas the lowest 
was recorded in the variants inoculated with C. tuberosa, which correlated with the lowest chlorophyll content.

Table 3. Effect of ectomycorrhizal fungus inoculation on leaf chlorophyll content and biometric parameters of B. napus L. on day 84 of cultivation in vivo (mean value \pm standard deviation). Values marked with different letters differ significantly at $p \leq 0.05$.

\begin{tabular}{cccccc}
\hline Variants of Experience & Chlorophyll $\left(\mathbf{m g ~ c m}^{3}\right)$ & Length of Shoots $(\mathbf{m m})$ & Number of Leaves & Fresh Biomass (g) & Dry Biomass (g) \\
\hline control & $0.815 \pm 0.412^{\mathrm{a}}$ & $665.3 \pm 121.9^{\mathrm{a}}$ & $7.3 \pm 1.4^{\mathrm{bc}}$ & $209.40 \pm 1.77^{\mathrm{b}}$ & $17.54 \pm 0.67^{\mathrm{b}}$ \\
\hline L. laccata & $0.718 \pm 0.412^{\mathrm{abc}}$ & $609.2 \pm 169.4^{\mathrm{ab}}$ & $8.4 \pm 3.5^{\mathrm{abc}}$ & $264.26 \pm 11.87^{\mathrm{a}}$ & $21.58 \pm 1.23^{\mathrm{a}}$ \\
\hline C. tuberosa & $0.387 \pm 0.222^{\mathrm{d}}$ & $473.8 \pm 91.2^{\mathrm{bcd}}$ & $8.4 \pm 2.6^{\mathrm{abc}}$ & $46.69 \pm 1.57^{\mathrm{d}}$ & $3.68 \pm 0.55^{\mathrm{e}}$ \\
\hline Clitocybe sp. & $0.579 \pm 0.237^{\mathrm{c}}$ & $530.0 \pm 122.1^{\mathrm{bcd}}$ & $9.1 \pm 1.9^{\mathrm{ab}}$ & $172.56 \pm 3.42^{\mathrm{c}}$ & $11.29 \pm 1.13^{\mathrm{d}}$ \\
\hline H. mesophaeum & $0.624 \pm 0.290^{\mathrm{abc}}$ & $646.60 \pm 137.53^{\mathrm{abc}}$ & $6.8 \pm 1.3^{\mathrm{c}}$ & $166.75 \pm 3.98^{\mathrm{c}}$ & $11.64 \pm 0.96^{\mathrm{d}}$ \\
\hline C. olla & $0.636 \pm 0.307^{\mathrm{abc}}$ & $507.00 \pm 126.67^{\mathrm{bcd}}$ & $9.8 \pm 2.0^{\mathrm{a}}$ & $195.42 \pm 5.06^{\mathrm{b}}$ & $14.54 \pm 1.42^{\mathrm{c}}$ \\
\hline
\end{tabular}

\subsection{Analysis of the Microorganisms Populations in the Soil after the Pot Experiment}

The effect of selected soil fungi on the abundance of microorganisms (bacterial colonies and fungi) in the inoculated soil from the pot experiment was analyzed. The highest number of bacterial colonies was observed in the soil of the variants inoculated with the C. olla, H. mesophaeum, and Clitocybe sp. (Figure 2A). In all soil samples tested that were inoculated with fungi, the number of these microorganisms was higher than in the control sample that contained only native fungal strains. This indicates the presence of the strains used as inoculum in the soil. The highest abundance of fungi was found in the variant containing the soil suspension inoculated with L. laccata fungi (Figure 2B). The difference in abundance of the studied microorganisms in the presence of Clitocybe sp. was relative to the control variant.

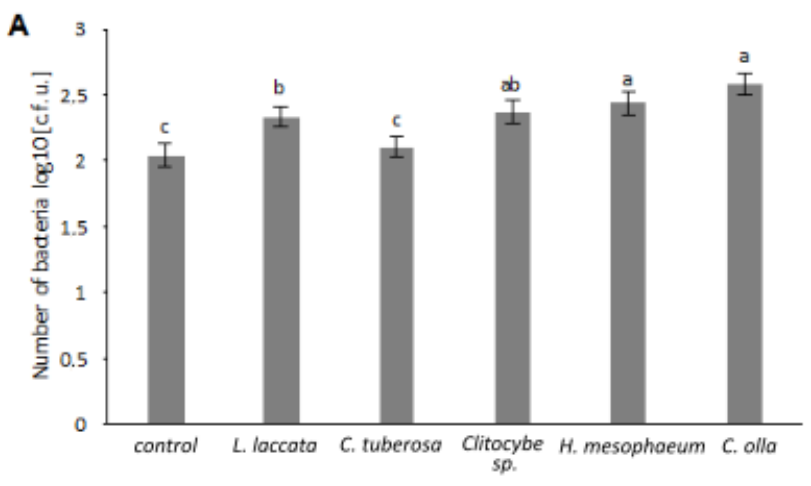

B

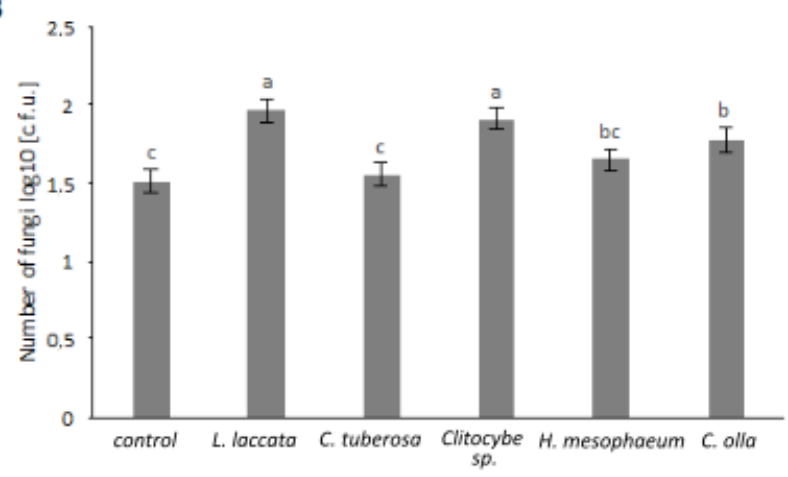

Figure 2. Abundance of bacterial (A) and fungal (B) colonies in soil after a pot experiment after inoculation with L. laccata, C. tuberosa, Clitocybe sp., H. mesophaeum, and C. olla. Values marked with different letters are significantly different at $p \leq 0.05$. 


\subsection{Analysis of IAA Production by Fungi}

It was found that all the fungi studied produced IAA. In the presence of tryptophan, an inducer of IAA synthesis, C. olla and C. tuberosa produced the highest amounts of this phytohormone. The strains of L. laccatta and H. mesophaeum showed a two-fold lower activity of IAA synthesis (Figure 3).

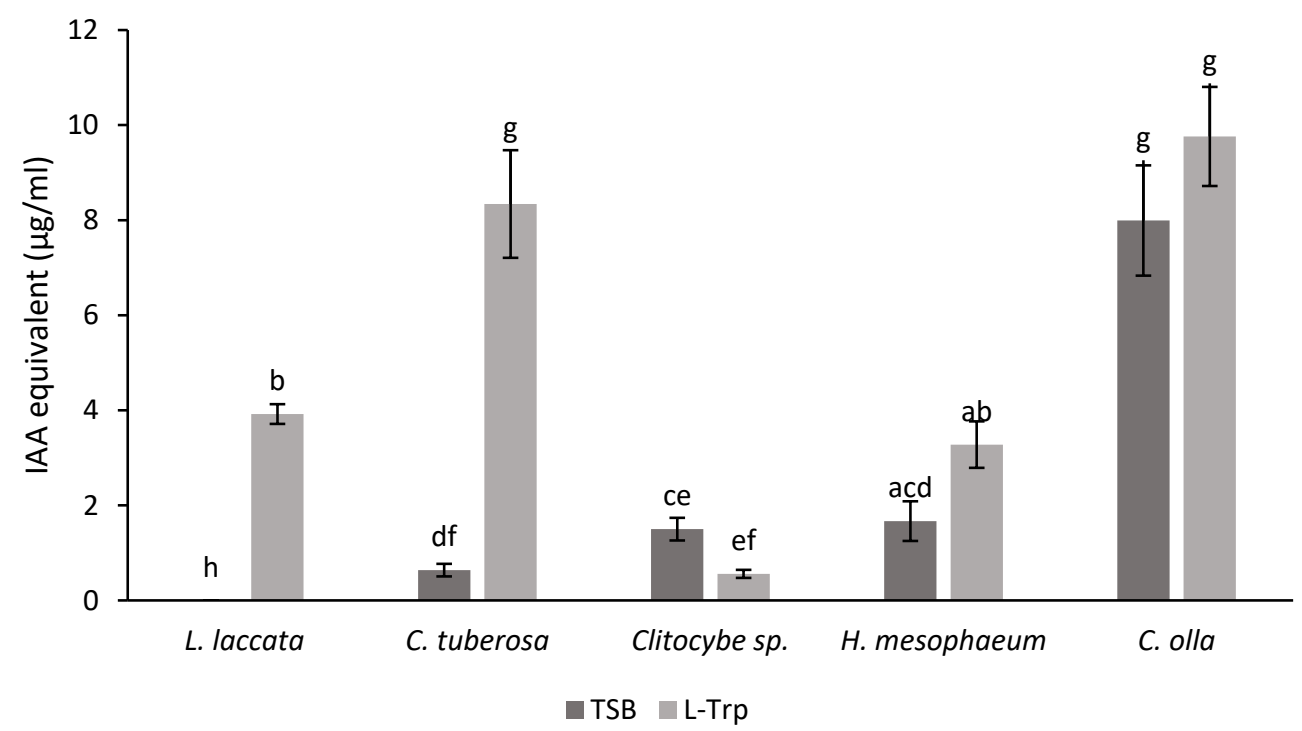

Figure 3. IAA production by studied fungi strains in TBS medium without and with L-tryptophan. Values marked with different letters are significantly different at $p \leq 0.05$.

3.5. In Silico Analysis of BnMT1-BnMT3 Sequences and Expression of These Genes in the Presence of Ectomycorrhizal Fungi

A search of the two databases of promoter regulatory elements, PlantCARE and PlantPan, showed that the BnMT2 and BnMT3 gene promoters contain the 5'TTGACC3 ${ }^{\prime}$ sequence of the W-box motif. This is a regulatory cis-element involved in the response to fungus elicitors (Table S2) [43]. Additionally, a second regulatory element of response to fungus elicitors was identified in the BnMT2 promoter sequence-an AT-rich sequence (5'TAAAATACT3', 5'TAAAATAT3') [44]. The expression of BnMT1-BnMT3 genes of rapeseed non-inoculated and inoculated with fungi was shown to change. The level of BnMT1 gene transcripts in each of the variants differed from the control. In the case of rapeseed inoculation with fungi such as L. laccata, C. tuberosa, H. mesophaeum, and C. olla, the mRNA level of this gene increased relative to the control (Figure 4A). Only for inoculation with Clitocybe sp. mycelium were there no significant differences from the control. BnMT2 gene transcripts were at a similar level in all leaves except for plants inoculated with C. olla fungus. The amount of mRNA in the leaves of these plants was significantly higher than in other variants (Figure 4B). Expression of the BnMT3 gene was significantly lower in the leaves of plants inoculated with L. laccata and C. tuberosa than in control plants (Figure $4 \mathrm{C}$ ). Inoculation with the remaining fungi did not significantly change the amounts of transcripts of this gene in rapeseed leaves (Figure $4 \mathrm{~A}-\mathrm{C}$ ). 

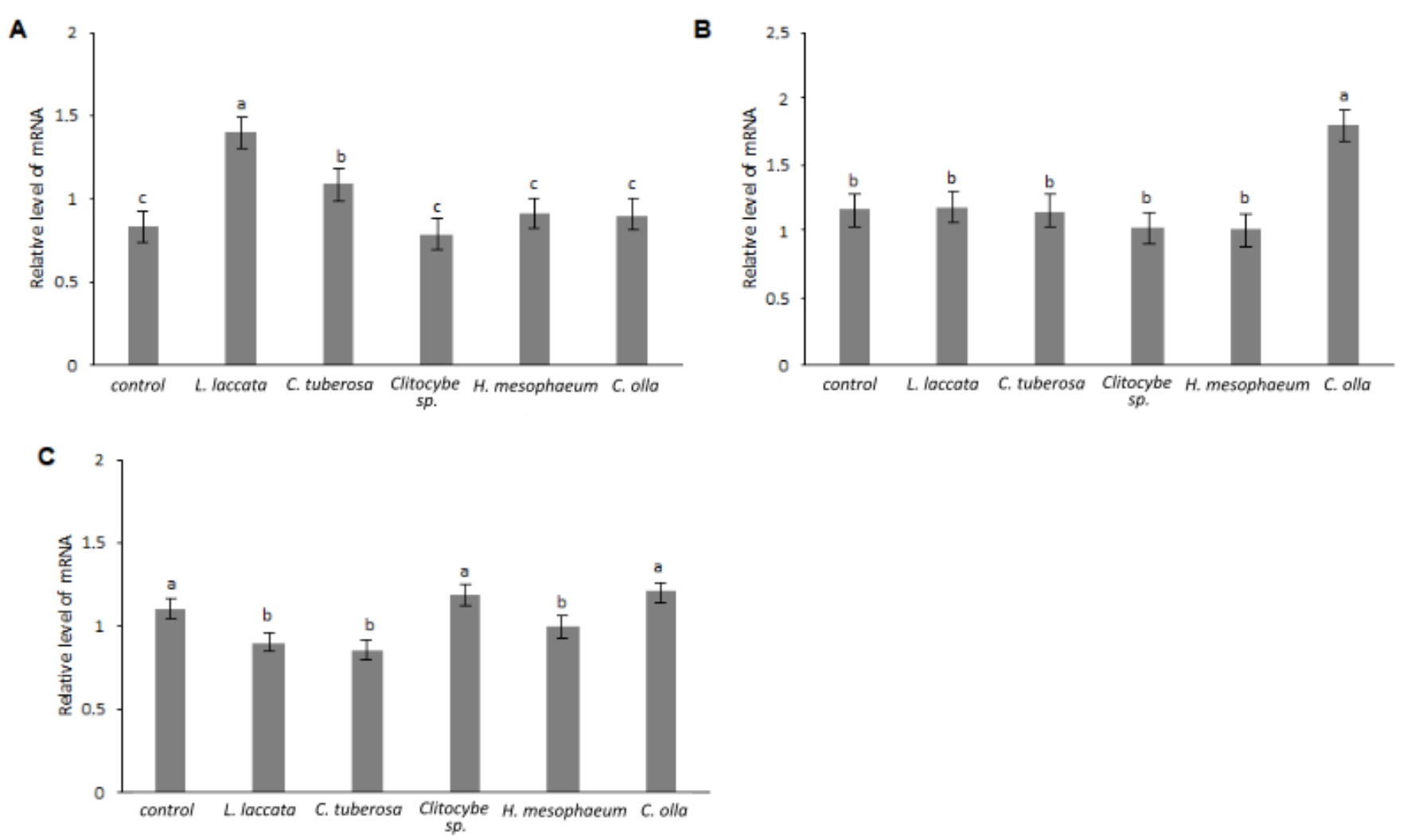

Figure 4. Relative mRNA level of genes (A) BnMT1, (B) BnMT2, and (C) BnMT3 in B. napus leaves non-inoculated (control) or inoculated with fungi. The graphs show the relative level of BnMT1-BnMT3 gene transcripts expressed in the ratio of the amount of $s q$ RT-PCR product for the BnMT1-BnMT3 genes to the amount of Bn5S gene product. Different lower case letter means statistical significance at $p \leq 0.05$.

\section{Discussion}

The neighborhood of forest and arable land favors soil-forming processes and natural colonization by fungi. The presented experiments investigated the influence of soil fungi living in forest areas on an arable crop. However, because not all crops form symbioses, it seemed important to test the hypothesis that the presence of soil fungi can positively influence microbiome and indirectly affect the growth of a non-symbiotic crop such as rapeseed.

The fungi L. laccata used in this study have the potential to form ectotrophic mycorrhizae [45]. In an in vitro experiment, rapeseed inoculated with L. laccata had a beneficial effect on root length and number of leaves. C. olla had a positive effect on lateral roots, shoot length and leaves. Inoculation of plants with L. laccata stimulated biomass accumulation, which was probably related to the greater number of leaves compared to control plants, although chlorophyll content was at a comparable level or photosynthesis was more efficient in plants inoculated with this fungus and control plants. This can be confirmed by the studies of Gao and $\mathrm{Wu}$ [46], who documented the positive effect of the fungus Laccaria aemthystea on photosystem function II in Pinus seedlings. A greater biomass of plants inoculated with L. laccata was also observed by Mortier et al. [47], who studied the effect of inoculation with this microorganisms on the growth of Pseudotsuga menziesii (Douglas fir). The stimulatory effect of L. laccata is probably also be related to its positive effect on soil microflora and macro- and microelement availability. Indirectly, this is evident from the marked difference in the abundance of soil fungi and bacteria observed in cultures of soil suspensions inoculated with this fungus. In previous studies, Dabrowska et al. [37] observed an indirect effect of arbuscular mycorrhizal fungi such as A. longula, G. geosporum, G. mosseae, and S. calospora on the growth of B. napus. Previous research showed that the above mycorrhizal fungi stimulated shoot elongation in a sterile medium, although the fresh biomass of the aboveground part of the rapeseed was lower than that of the 
control plants. Plants growing in the presence of AMF (arbuscular mycorrhizal fungi) in a non-sterile medium were characterized by greater fresh biomass, shoot length, and number of internodes than plants growing in a sterile medium, probably due to the positive effect of naturally occurring microorganisms in the soil, e.g., rhizosphere bacteria [37].

In the present study, the use of the ectomycorrhizal fungus $H$. mesophaeum as inoculum did not result in significant visible changes in biometric parameters. However, plants inoculated with this fungus in the in vivo experiment had about $20 \%$ lower biomass compared to control plants. Studies by Hrynkiewicz et al. [48] revealed that the presence of the fungus $H$. mesophaeum did not affect the growth of Salix viminalis. Only co-inoculation of willow with H. mesopheum and Bacillus cereus bacteria promoted biomass production of willow growing in soil contaminated with heavy metals. Inoculated $S$. viminalis plants showed an increase in nitrogen, potassium, phosphorus, and zinc content in shoots. Inoculations with strains of the genera Hebeloma and Laccaria are available and recommended for forest nurseries, which maintain plant condition and health regardless of changes in environmental conditions [49]. The average number of lateral roots and stimulation of shoot growth and development (stem length and number of leaves) was highest in seedlings inoculated with the fungus C. olla after 84 days of growing plants in soil. The growth-promoting effect of this mycelial species is not sufficiently visible due to its slow growth as observed under laboratory conditions (Figure 1). Possibly, the development of the above-ground part of the plants treated with the $C$. olla fungus was related to the increased number of autochthonous (resident) bacteria, which were most numerous in the soil inoculated with the C. olla fungus.

It seems that, of the fungi studied, the presence of L. laccata and C. olla had a beneficial effect on rapeseed and the soil microbiome. Therefore, field trials to confirm the protective role of this fungus in relation to rapeseed are warranted. Several interesting studies have pointed out the role of auxin as plant signaling hormones in plant responses to plant growth-promoting fungi (PGPF) and, in particular, described their involvement in the control of shoot and root development [50]. The inoculated plants showed expression of auxin-regulated genes. As expected, mutations in genes involved in auxin transport or auxin signaling, $A U X 1, B I G, E I R 1$, and $A X R 1$, reduced the growth-promoting and root development-promoting effects of T. virens inoculation in Arabidopsis. These results suggest that the promotion of plant growth by T. virens occurs through the classical auxin response pathway [8]. Similarly, Piriformosporia indica-induced expression of auxin-regulated genes was reported in barley [51] and in Chinese cabbage [9], and its induction was crucial for the strong growth-promoting effect of the fungus. It is suggested that microbial auxin may play a role in altering auxin biosynthesis or signal transduction in the host [52]. Sirrenberg et al. [53] previously found that the phenotype resulting from the interaction of Arabidopsis with Pi. indica is mimicked by an external application of IAA at a lower concentration than that of the fungus, suggesting a role for exogenous auxin. Similarly, Contreras-Cornejo et al. [8] showed that treatment with IAA and indole-3-acetaldehyde rescues the root hair defect phenotype of the rhd6 mutant. This result may suggest that microbial auxin is involved in the suppression of root hair formation of rhd6. Thus, auxin may act as a reciprocal signaling molecule in the interaction between plants and microbes. Microorganisms that form various symbiotic interactions with plants play an important role in increasing the efficiency of plant production and in enabling plant colonization and survival in natural environments. Synthesis of phytohormones by microorganisms is necessary to form lasting associations with plant roots. Plant hormones cause cell division and differentiation in the meristematic root tissue so that the root elongates and forms more hairs and branches [54].

Several mycorrhizal fungi that may be present in forest soils were selected for the study. Because regulatory sequences responsible for plant responses to fungal elicitors have been identified in the promoters of the MT A. thaliana and O. sativa genes [27], we suppose that these may be involved in plants' adaptation to changes in environmental conditions. The change in the expression of plant metallothionein genes is related to the action of various 
factors, both endogenous and exogenous, on the body [38]. It seems that the functions of MTs in plants are not limited to heavy metals, but that these proteins may act as stress proteins, protecting the body from various adverse environmental factors and enabling adaptation to changing conditions $[21,23,38]$. The expression profile of metallothionein plant genes can change under the influence of viruses, bacteria, and fungi. In silico analyses of the BnMT1-BnMT3 sequence revealed the presence of regulatory elements for the response to fungal elicitors (W-box, AT-rich element). Similarly, in previous studies, Dabrowska et al. [27] demonstrated the presence of a W-box motif in five metallothionein promoters, including four in Arabidopsis (AtMT1B, AtMT2A, AtMT2B, and AtEC) and $O$. sativa OsMT2B. The effect that infection with pathogenic fungi has on altering the expression of plant MTs is described in detail in the literature. Type 2 and 3 MTs in Abutilon theophrasti were expressed at higher levels on the first day of infection with Colletotrichum coccodes than in control plants [55]. Miles et al. [56] also compared the expression level of MT genes in response to Colletotrichum acutatum in two blueberry cultivars. Studies have confirmed that one of the genes overexpressed during pathogen-plant interaction is MT. Moreover, the increase in the expression of this gene was greater in a cultivar resistant to the fungal pathogen. Infection of transformed $A$. thaliana plants with the pathogenic fungus Pernospora parasitica results in different expression of the Gus reporter gene of the type 1 promoter of $B$. napus $M T$ than in non-inoculated plants. In control plants, expression of the reporter gene was restricted only to the vascular bundles after seven days, whereas in infected plants it covered the entire cotyledon [29]. The expression of MTs genes is also changed in plants inoculated with bacteria that promote their growth, which is confirmed by the research of Hrynkiewicz et al. [48]. In contrast, in oil palm (Elaeis guineensis), the expression of type-3 MT increased in roots and leaves as a result of inoculation with the pathogenic fungus Ganoderma bininense and the symbiotic fungus Trichoderma harzianum [30]. Research by Voiblet et al. [57] showed that MT expression was downregulated in Eucalypus globus in the presence of the fungus Pisolithus tinctorius. PnMTA transcripts were found by RiveraBicerell et al. [58] in the roots of peas inoculated with Glomus intraradices compared to plants not inoculated with AMF. By contrast, Dabrowska et al. [59] did not find a change in the level of transcripts of the Brassica napus type-2 metallothionein gene (BnMT2) in roots in the presence of AM fungi spores, but found an increased number of transcripts in plant leaves after AM inoculation in soil that had been cleared of other microorganisms. High levels of LcMT2 were also observed in Lycopersicon esculentum growing in soil containing heavy metals, but the presence of AMF caused a decrease in expression of this gene [60]. By contrast, gene expression in Populus alba (PaMT1-3) varied depending on the presence of AMF and soil type [61]. Changes in the level of MT expression are also influenced by such factors as: phytohormones [9], physiological drought [62,63], osmotic stress [64], temperature fluctuations [65], and excessively high or low light intensity [66]. Mechanical injuries to plants, which contribute to the formation of reactive oxygen species (ROS) [67], also induce the expression of MT genes. One example is the induction of expression by MT1, MT2, and MT3 in B. rapa [68]. Research by Mierek-Adamska et al. [30] showed that $B n M T 1-B n M T 4$ in rapeseed perform an antioxidant function when they are over-expressed in bacteria. Under stress conditions, plants activate additional processes to allow survival, with genes encoding oxidative enzymes and MTs being expressed [69].

\section{Conclusions}

B. napus, a non-mycorrhizal plant, interacts with selected fungi. Positive effects were demonstrated for L. laccata and C. olla. The fungi stimulated the growth of the roots and the above-ground part of the plants. The presence of the tested fungi, especially C. olla, increased the number of microorganisms in the soil, especially bacteria. This may indicate an indirect positive effect of this fungus on the growth and development of rapeseed.

The results of the in silico analyses concerning the promoter sequences of metallothionein genes were confirmed experimentally. The presence of regulatory sequences for responses to fungal elicitors suggests the involvement of metallothionein interaction be- 
tween plant and microorganism (fungus). It seems to us that MTs are necessary, firstly, to remove reactive oxygen species during the stimulation of plant growth by fungi, when there is increased uptake of water and other nutrients, resulting in more intense cell division, where ROS occurs. Then the plants also have an increased need for metal ions such as $\mathrm{Cu}$ and $\mathrm{Zn}$, whose reservoir is precisely metallothioneins.

We intend to continue research to characterize microorganisms in detail. The research will focus on checking the protective role of fungi, especially L. laccata and C. olla, against rape pathogens. The long-term goal is to develop a biopreparation that would support the growth of oilseed rape under conditions of dehydration stress and pathogen attack.

Supplementary Materials: The following are available online at https: / www.mdpi.com/article / 10.3390 /agronomy11122475/s1, Table S1. Access numbers, length, and chromosomal location of the analysed rapeseed $M T$ promoter sequences obtained from the NCBI database, Table S2. Selected cis-regulatory elements found in the rapeseed MT promoter sequences.

Author Contributions: Conceptualization, G.B.D.; methodology, G.B.D., I.S.-B., W.K., A.T. and Z.G.; software, H.P.D., Z.G., W.K. and I.S.-B.; validation, Z.G., W.K., H.P.D. and Z.G.; formal analysis, Z.G., W.K. and I.S.-B.; investigation, G.B.D., Z.G., A.T. and W.K.; resources, G.B.D.; data curation, G.B.D.; writing-original draft preparation, G.B.D., Z.G. and I.S.-B.; writing-review and editing, G.B.D. and I.S.-B.; visualization, A.T., Z.G., W.K., I.S.-B.; supervision, G.B.D., H.P.D.; project administration, G.B.D.; funding acquisition, G.B.D. All authors have read and agreed to the published version of the manuscript.

Funding: The research was financed from the funds of the Nicolaus Copernicus University in Torun intended for basic research.

Institutional Review Board Statement: Not applicable.

Informed Consent Statement: Not applicable.

Data Availability Statement: Not applicable.

Acknowledgments: The authors thank Katarzyna Hrynkiewicz for making the fungi available for research.

Conflicts of Interest: The authors declare no conflict of interest.

\section{References}

1. Korelewski, K. Review and systematics of works increasing utility value of non-urban lands. Przegl. Nauk. Inz. Ksztalt. Sr. 2006, 2, 27-34.

2. Baldi, E. Soil-Plant Interaction: Effects on Plant Growth and Soil Biodiversity. Agronomy 2021, 11, 2378. [CrossRef]

3. Bashan, Y.; Holguin, G.; De-Bashan, L.E. Azospirillum-plant relationships: Physiological, molecular, agricultural, and environmental advances (1997-2003). Can. J. Microbiol. 2004, 50, 521-577. [CrossRef]

4. Dabrowska, G.; Zdziechowska, E. The role of rhizobacteria in the stimulation of the growth and development processes and protection of plants against environmental factors. Prog. Plant Prot. 2015, 55, 498-506. [CrossRef]

5. Hrynkiewicz, K.; Szymańska, S.; Piernik, A.; Thiem, D. Ectomycorrhizal Community Structure of Salix and Betula spp. at a Saline Site in Central Poland in Relation to the Seasons and Soil Parameters. Water Air Soil Pollut. 2015, 226, 99. [CrossRef] [PubMed]

6. Aguilar-Paredes, A.; Valdés, G.; Nuti, M. Ecosystem Functions of Microbial Consortia in Sustainable Agriculture. Agronomy 2020, 10, 1902. [CrossRef]

7. Znajewska, Z.; Dabrowska, G.B.; Narbutt, O. Trichoderma viride strains stimulating the growth and development of winter rapeseed (Brassica napus L.). Prog. Plant Prot. 2018, 58, 264-269. [CrossRef]

8. Contreras-Cornejo, H.A.; Macías-Rodríguez, L.; Cortés-Penagos, C.; López-Bucio, J. Trichoderma virens, a Plant Beneficial Fungus, Enhances Biomass Production and Promotes Lateral Root Growth through an Auxin-Dependent Mechanism in Arabidopsis. Plant Physiol. 2009, 149, 1579-1592. [CrossRef] [PubMed]

9. Ahn, Y.O.; Kim, S.H.; Lee, J.; Kim, H.; Lee, H.-S.; Kwak, S.-S. Three Brassica rapa metallothionein genes are differentially regulated under various stress conditions. Mol. Biol. Rep. 2011, 39, 2059-2067. [CrossRef]

10. Bonfante, P.; Genre, A. Mechanisms underlying beneficial plant-fungus interactions in mycorrhizal symbiosis. Nat. Commun. 2010, 1, 48. [CrossRef]

11. Landeweert, R.; Hoffland, E.; Finlay, R.; Kuyper, T.W.; van Breemen, N. Linking plants to rocks: Ectomycorrhizal fungi mobilize nutrients from minerals. Trends Ecol. Evol. 2001, 16, 248-254. [CrossRef]

12. Jentschke, G.; Godbold, D.L. Metal toxicity and ectomycorrhizas. Physiol. Plant. 2000, 109, 107-116. [CrossRef] 
13. Wallander, H.; Wickman, T. Biotite and microcline as potassium sources in ectomycorrhizal and non-mycorrhizal Pinus sylvestris seedlings. Mycorrhiza 1999, 9, 25-32. [CrossRef]

14. Wallander, H. Use of strontium isotopes and foliar K content to estimate weathering of biotite induced by pine seedlings colonised by ectomycorrhizal fungi from two different soils. Plant Soil 2000, 222, 215-229. [CrossRef]

15. Wallander, H. Uptake of P from apatite by Pinus sylvestris seedlings colonised by different ectomycorrhizal fungi. Plant Soil 2000, 218/2, 249-256. [CrossRef]

16. Luo, Z.-B.; Janz, D.; Jiang, X.; Göbel, C.; Wildhagen, H.; Tan, Y.; Rennenberg, H.; Feussner, I.; Polle, A. Upgrading Root Physiology for Stress Tolerance by Ectomycorrhizas: Insights from Metabolite and Transcriptional Profiling into Reprogramming for Stress Anticipation. Plant Physiol. 2009, 151, 1902-1917. [CrossRef]

17. Peay, K.G.; Bruns, T.D. Spore dispersal of basidiomycete fungi at the landscape scale is driven by stochastic and deterministic processes and generates variability in plant-fungal interactions. New Phytol. 2014, 204, 180-191. [CrossRef] [PubMed]

18. Peng, M.; Pontes, M.V.A.; Hainaut, M.; Henrissat, B.; Hilden, K.; Mäkelä, M.; de Vries, R.P. Comparative analysis of basidiomycete transcriptomes reveals a core set of expressed genes encoding plant biomass degrading enzymes. Fungal Genet. Biol. 2017, 112, 40-46. [CrossRef]

19. Caesar-TonThat, T.-C.; Cochran, V.L. Soil aggregate stabilization by a saprophytic lignin-decomposing basidiomycete fungus I. Microbiological aspects. Biol. Fertil. Soils 2000, 32, 374-380. [CrossRef]

20. Caesar-Tonthat, T.C.; Cochran, V.L. Role of a Saprophytic Basidiomycete Soil Fungus in Aggregate Stabilization. In Proceedings of the 10th International Soil Conservation Organization Meeeting, West Lafayette, IN, USA, 24-29 May 1999; pp. 575-579.

21. Freisinger, E. Spectroscopic characterization of a fruit-specific metallothionein: M. acuminata MT3. Inorg. Chim. Acta 2007, 360, 369-380. [CrossRef]

22. Capdevila, M.; Atrian, S. Metallothionein protein evolution: A miniassay. J. Biol. Inorg. Chem. 2011, 16, 977-989. [CrossRef] [PubMed]

23. Leszczyszyn, O.I.; Imam, H.T.; Blindauer, C.A. Diversity and distribution of plant metallothioneins: A review of structure, properties and functions. Metallomics 2013, 5, 1146-1169. [CrossRef] [PubMed]

24. Koszucka, A.M.; Dąbrowska, G. Plant metallothionein. Adv. Biol. Cell 2006, 33, 285-302.

25. Usha, B.; Venkataraman, G.; Parida, A. Heavy metal and abiotic stress inducible metallothionein isoforms from Prosopis juliflora (SW) D.C. show differences in binding to heavy metals in vitro. Mol. Genet. Genom. 2008, 281, 99-108. [CrossRef] [PubMed]

26. González, A.; Sáez, C.A.; Moenne, A. Copper-induced activation of TRPs and VDCCs triggers a calcium signature response regulating gene expression in Ectocarpus siliculosus. Peer J. 2018, 6, e4556. [CrossRef]

27. Dabrowska, G.; Hrynkiewicz, K.; Trejgell, A. Do Arbuscular Mycorrhizal Fungi Affect Metallothionein MT2 Expression In Brassica Napus L. Roots? Acta Biol. Cracov. Bot. 2012, 54, 34-39. [CrossRef]

28. Guo, W.; Bundithya, W.; Goldsbrough, P.B. Characterization of the Arabidopsis metallothionein gene family: Tissue-specific expression and induction during senescence and in response to copper. New Phytol. 2003, 159, 369-381. [CrossRef]

29. Ren, Y.; Liu, Y.; Chen, H.; Li, G.; Zhang, X.; Zhao, J. Type 4 metallothionein genes are involved in regulating Zn ion accumulation in late embryo and in controlling early seedling growth in Arabidopsis. Plant Cell Environ. 2011, 35, 770-789. [CrossRef]

30. Mierek-Adamska, A.; Kotowicz, K.; Goc, A.; Boniecka, J.; Berdychowska, J.; Dabrowska, G.B. Potential involvement of rapeseed (Brassica napus L.) metallothioneins in the hydrogen peroxide-induced regulation of seed vigour. J. Agron. Crop. Sci. 2019, 205, 598-607. [CrossRef]

31. Dabrowska, G.; Mierek-Adamska, A.; Goc, A. Characterisation of Brassica napus L. metallothionein genes (BnMTs) expression in organs and during seed germination. Aust. J. Crop Sci. 2013, 7, 1324-1332.

32. Glenn, M.G.; Chew, F.S.; Williams, P. Hyphal penetration of Brassica (Cruciferae) roots by a vesicular-arbuscular mycorrizal fungus. New Phytol. 1985, 99, 463-472. [CrossRef]

33. Tommerup, I. Effect of soil water potential on spore germination by vesicular-arbuscular mycorrhizal fungi. Trans. Br. Mycol. Soc. 1984, 83, 193-202. [CrossRef]

34. Ishimoto, H.; Fukushi, Y.; Yoshida, T.; Tahara, S. Rhizopus and Fusarium are Selected as Dominant Fungal Genera in Rhizospheres of Brassicaceae. J. Chem. Ecol. 2000, 26, 2387-2399. [CrossRef]

35. Qiang, X.; Weiss, M.; kogel, K.H.; Schäfer, P. Piriformospora indica-A mutualistic basidiomycete with an exceptionally large plant host range. Mol. Plant Pathol. 2011, 13, 508-518. [CrossRef]

36. Zhang, Q.; Zhang, J.; Yang, L.; Zhang, L.; Jiang, D.; Chen, W.; Li, G. Diversity and biocontrol potential of endophytic fungi in Brassica napus. Biol. Control. 2014, 72, 98-108. [CrossRef]

37. Dabrowska, G.; Baum, C.; Trejgell, A.; Hrynkiewicz, K. Impact of arbuscular mycorrhizal fungi on the growth and expression of gene encoding stress protein-Metallothionein BnMT2 in the non-host crop Brassica napus L. J. Plant Nutr. Soil Sci. 2014, 177, 459-467. [CrossRef]

38. Dabrowska, G. Plant Metallothioneins: Putative Functions Identified by Promoter Analysis in silico. Acta Biol. Cracov. Bot. 2012, 54, 109-120. [CrossRef]

39. Gravel, V.; Antoun, H.; Tweddell, R.J. Growth stimulation and fruit yield improvement of greenhouse tomato plants by inoculation with Pseudomonas putida or Trichoderma atroviride: Possible role of indole acetic acid (IAA). Soil Biol. Biochem. 2007, 39, 1968-1977. [CrossRef] 
40. Chomczynski, P.; Sacchi, N. Single-step method of RNA isolation by acid guanidinium thiocyanate-phenol-chloroform extraction. Anal. Biochem. 1987, 162, 156-159. [CrossRef]

41. Dabrowska, G.; Hrynkiewicz, K.; Trejgell, A.; Baum, C. The effect of plant growth-promoting rhizobacteria on the phytoextraction of Cd and Zn by Brassica napus L. Int. J. Phytoremediat. 2017, 19, 597-604. [CrossRef]

42. Higo, K.; Ugawa, Y.; Iwamoto, M.; Korenaga, T. Plant cis-acting regulatory DNA elements (PLACE) database: 1999. Nucleic Acids Res. 1999, 27, 297-300. [CrossRef] [PubMed]

43. Hammer, Ø.; Harper, D.A.T.; Ryan, P.D. PAST: Paleontological Statistics Software Package for Education and Data Analysis. Palaeontol. Electron. 2001, 4, 9.

44. Ülker, B.; E Somssich, I. WRKY transcription factors: From DNA binding towards biological function. Curr. Opin. Plant Biol. 2004, 7, 491-498. [CrossRef]

45. Matarasso, N.; Schuster, S.; Avni, A. A Novel Plant Cysteine Protease Has a Dual Function as a Regulator of 1-Aminocyclopropane1-Carboxylic Acid Synthase Gene Expression. Plant Cell 2005, 17, 1205-1216. [CrossRef]

46. Chakravarty, P.; Hwang, S.F. Effect of an ectomycorrhizal fungus, Laccaria laccata, on Fusarium damping-off in Pinus banksiana seedlings. For. Pathol. 1991, 21, 97-106. [CrossRef]

47. Gao, Y.; Wu, X. Effects of several ectomycorrhizal fungi on the chlorophyll content and chlorophyll fluorescence parameters in different pine seedlings. J. Najing For. Univ. 2010, 34, 9-12.

48. Hrynkiewicz, K.; Dabrowska, G.; Baum, C.; Niedojadło, K.; Leinweber, P. Interactive and Single Effects of Ectomycorrhiza Formation and Bacillus cereus on Metallothionein MT1 Expression and Phytoextraction of Cd and Zn by Willows. Water Air Soil Pollut. 2011, 223, 957-968. [CrossRef] [PubMed]

49. Kowalski, T. Occurrence and associated symptoms of Sirococcus conigenus on Picea abies. Phytopathologia 2010, 58, 53-61.

50. Hossain, M.M.; Sultana, F.; Islam, S. Plant Growth-Promoting Fungi (PGPF): Phytostimulation and Induced Systemic Resistance; Springer: Singapore, 2017; Volume 2, ISBN 9789811065934.

51. Schäfer, P.; Pfiffi, S.; Voll, L.M.; Zajic, D.; Chandler, P.M.; Waller, F.; Scholz, U.; Pons-Kühnemann, J.; Sonnewald, S.; Sonnewald, U.; et al. Manipulation of plant innate immunity and gibberellin as factor of compatibility in the mutualistic association of barley roots with Piriformospora indica. Plant J. 2009, 59, 461-474. [CrossRef]

52. Sukumar, P.; Maloney, G.S.; Muday, G.K. Localized Induction of the ATP-Binding Cassette B19 Auxin Transporter Enhances Adventitious Root Formation in Arabidopsis. Plant Physiol. 2013, 162, 1392-1405. [CrossRef]

53. Sirrenberg, A.; Göbel, C.; Grond, S.; Czempinski, N.; Ratzinger, A.; Karlovsky, P.; Santos, P.; Feussner, I.; Pawlowski, K. Piriformospora indica affects plant growth by auxin production. Physiol. Plant. 2007, 131, 581-589. [CrossRef] [PubMed]

54. Steenhoudt, O.; Vanderleyden, J. Azospirillum, a free-living nitrogen-fixing bacterium closely associated with grasses: Genetic, biochemical and ecological aspects. FEMS Microbiol. Rev. 2000, 24, 487-506. [CrossRef] [PubMed]

55. Dauch, A.L.; Jabaji, S. Metallothionein and bZIP Transcription Factor Genes from Velvetleaf and Their Differential Expression Following Colletotrichum coccodes Infection. Phytopathology 2006, 96, 1116-1123. [CrossRef]

56. Miles, T.D.; Day, B.; Schilder, A.C. Identification of differentially expressed genes in a resistant versus a susceptible blueberry cultivar after infection by Colletotrichum acutatum. Mol. Plant Pathol. 2011, 12, 463-477. [CrossRef] [PubMed]

57. Voiblet, C.; Duplessis, S.; Encelot, N.; Martin, F. Identification of symbiosis-regulated genes in Eucalyptus globulus-Pisolithus tinctorius ectomycorrhiza by differential hybridization of arrayed cDNAs. Plant J. 2001, 25, 181-191. [CrossRef]

58. Rivera-Becerril, F.; Van Tuinen, D.; Martin-Laurent, F.; Metwally, A.; Dietz, K.-J.; Gianinazzi, S.; Gianinazzi-Pearson, V. Molecular changes in Pisum sativum L. roots during arbuscular mycorrhiza buffering of cadmium stress. Mycorrhiza 2005, 16, 51-60. [CrossRef] [PubMed]

59. Mortier, F.; Le Tacon, F.; Garbaye, J. Effect of inoculum type and inoculation dose on ectomycorrhizal development, root necrosis and growth of Douglas fir seedlings inoculated with Laccaria laccata in a nursery. Ann. Sci. For. 1988, 45, 301-310. [CrossRef]

60. Ouziad, F.; Hildebrandt, U.; Schmelzer, E.; Bothe, H. Differential gene expressions in arbuscular mycorrhizal-colonized tomato grown under heavy metal stress. J. Plant Physiol. 2005, 162, 634-649. [CrossRef]

61. Cicatelli, A.; Lingua, G.; Todeschini, V.; Biondi, S.; Torrigiani, P.; Castiglione, S. Arbuscular mycorrhizal fungi restore normal growth in a white poplar clone grown on heavy metal-contaminated soil, and this is associated with upregulation of foliar metallothionein and polyamine biosynthetic gene expression. Ann. Bot. 2010, 106, 791-802. [CrossRef]

62. Berta, M.; Giovannelli, A.; Potenza, E.; Traversi, M.L.; Racchi, M.L. Type 3 metallothioneins respond to water deficit in leaf and in the cambial zone of white poplar (Populus alba). J. Plant Physiol. 2009, 166, 521-530. [CrossRef]

63. Gu, L.; Pallardy, S.G.; Hosman, K.P.; Sun, Y. Drought-influenced mortality of tree species with different predawn leaf water dynamics in a decade-long study of a central US forest. Biogeosciences 2015, 12, 2831-2845. [CrossRef]

64. Singh, R.K.; Anandhan, S.; Singh, S.; Patade, V.Y.; Ahmed, Z.; Pande, V. Metallothionein-like gene from Cicer microphyllum is regulated by multiple abiotic stresses. Protoplasma 2010, 248, 839-847. [CrossRef]

65. Ren, Y.; Zhao, J. Functional analysis of the rice metallothionein gene OsMT2b promoter in transgenic Arabidopsis plants and rice germinated embryos. Plant Sci. 2009, 176, 528-538. [CrossRef]

66. Dong, C.-J.; Wang, Y.; Yu, S.-S.; Liu, J.-Y. Characterization of a Novel Rice Metallothionein Gene Promoter: Its Tissue Specificity and Heavy Metal Responsiveness. J. Integr. Plant Biol. 2010, 52, 914-924. [CrossRef]

67. Xue, T.; Li, X.; Zhu, W.; Wu, C.; Yang, G.; Zheng, C. Cotton metallothionein GhMT3a, a reactive oxygen species scavenger, increased tolerance against abiotic stress in transgenic tobacco and yeast. J. Exp. Bot. 2008, 60, 339-349. [CrossRef] [PubMed] 
68. Hassinen, V.H.; Tervahauta, A.I.; Schat, H.; Kärenlampi, S.O. Plant metallothioneins-Metal chelators with ROS scavenging activity? Plant Biol. 2010, 13, 225-232. [CrossRef] [PubMed]

69. Dąbrowska, G.; Kata, A.; Goc, A.; Szechyńska-Hebda, M.; Skrzypek, E. Characteristics of the plant ascorbate peroxidase family. Acta Biol. Crac. Ser. Bot. 2007, 49, 7-17. 